\title{
DETERMINATION OF DRYING TIME OF THE RAMMED EARTH WALLS
}

\author{
Tereza Plaček Otcovská*, Barbora Mužíková, Pavel Padevět \\ Czech Technical University in Prague, Faculty of Civil Engineering, Thákurova 7, 16629 Prague 6, Czech \\ Republic \\ * corresponding author: tereza.otcovska@fsv.cvut.cz
}

\begin{abstract}
The unburned earth is a building material with long history of use. Buildings made of unburned clay are all over the world. But at present, unburned earth is minority building material and its properties are not sufficiently investigated. The rammed earth is one of main kind of unburned earth. This paper is focused on drying rate of the rammed earth of known composition. The significant part of the paper is focused on principle of our own research and the main idea of our research is explained here. The second part of the paper is devoted to drying rate experiment and measured results from this experiment. Determination of drying time of universal rammed earth walls is the main result of the experiment.
\end{abstract}

KEYwords: Rammed earth, unburned earth, clay, sand, water coefficient, drying rate, drying time.

\section{INTRODUCTION}

Importance of the unburned earth in construction industry is minor, but there are a few reasons why the research of this building material is important. Recently, there has been a growing interest in unburned earth which has resulted in a number of scientific articles on this topic. The growing interest in this historic building material is evident in construction industry too (see Fig. 1). I can see in my practice of civil engineer that more and more people choose the unburned earth for build of their houses. The growing interest is the first reason why carry out research in the unburned earth (see Fig. 2] [1, 2].

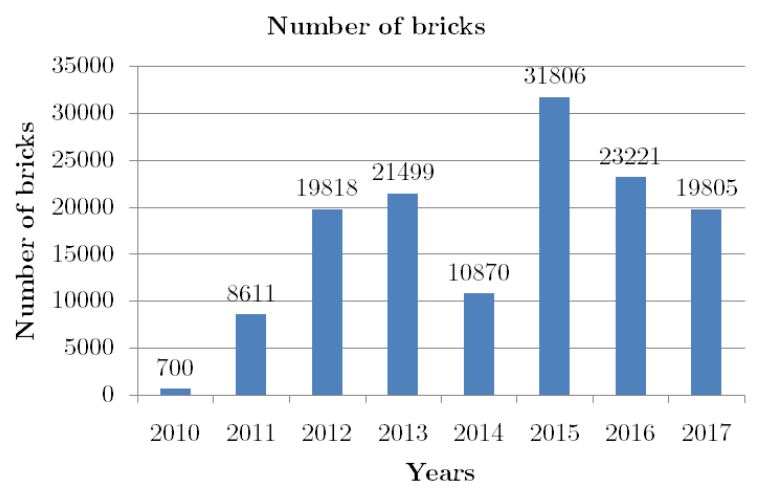

FigURE 1. Sales of unfired bricks by HELUZ cihlářský průmysl v.o.s.

The second reason is a need for reconstruction of historic buildings. There are many earth buildings in the world and in the Czech Republic that need reconstruction. It is very important to have the knowledges of unburned earth properties for correct reconstruction of this buildings [3].

Third, an earth building is a good way for sustain-

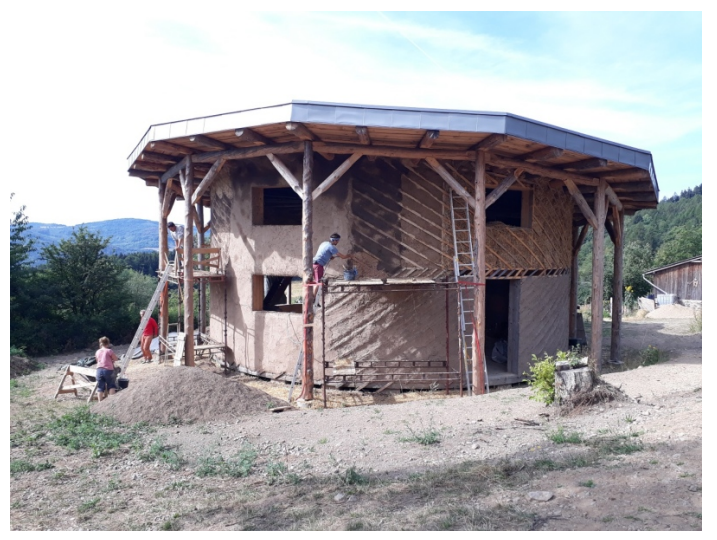

Figure 2. Building of family house from straw and earth in Klášterecká Jeseň.

able development in the construction industry. The energy needed for production of the unburned clay is minimal and the energy for demolition of the earth construction is small, because earth waste can be completely recycled and earth waste does not need to be stored in a waste dump. A good indicator is primary energy investment (PEI). PEI is an energy used during live cycle of building materials $8-11$.

The primary complication about the properties of the unburned earth is in composition of the earth. The properties depend on composition of the earth and the composition of earth can be very variable. Currently, a design of load bearing structures from rammed earth needs a lot of civil engineer's experiences because norms or methodology does not exist for the design of unburned earth constructions in the Czech Republic. The reliable methodology is very important for easier design of the earth buildings. That are reasons why is necessary to carry out the research focused on the composition of earth mixture and prop- 


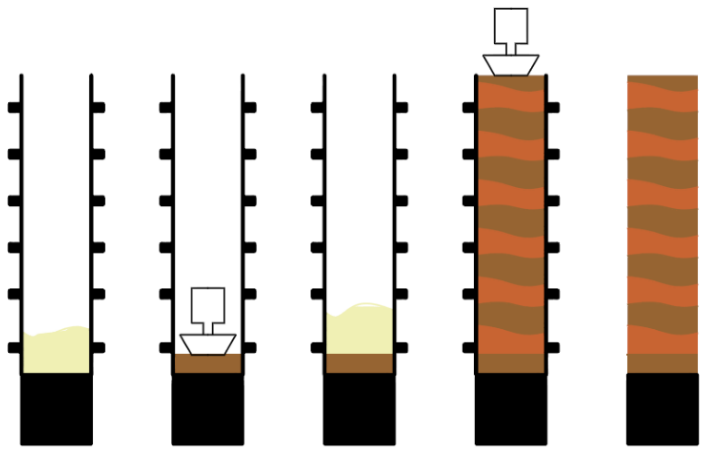

FiguRE 3. The rammed earth.

erties of the final earth structures. The reliable dates from the research should be used for the creation of the methodology [3, 12, 13].

The earth constructions can be produced of the earth mixture without or with inorganic binder. The inorganic binder can improve water resistance of unburned earth. But the inorganic binders are not necessary for the earth constructions. There are old historic buildings and there are researches which proved that unburned earth can be sufficiently resistant against the moisture. The important reason for using unburned earth without the inorganic binders is environment and the sustainable development. The unburned earth with inorganic binder is not possible to recycle easily. This are the reasons why our research is focused on the properties of unburned earth without additives [3, 8, 14, 16.

The earth construction can be produced from the earth mixture in several ways. The elementary type of the earth construction is the rammed earth. This paper is focused on the rammed earth. The principle of rammed earth technology is pressing down layers of the earth mixture to a formwork (see Fig. 3). The rammed earth walls are usually used like load-bearing structures. That is the reason why the mechanical properties and information about drying rate are very important [3, 13, 17.

The main topic of this paper is the drying rate and drying time. Information about the drying rate and drying time are important, because the drying is the main way how the unburned earth gains its final mechanical properties. The rammed earth construction are usually load-bearing types and it is necessary to know when the rammed earth construction is possible to load.

\section{The Idea of Our Research}

As stated in the introduction, the norm or relevant instructions about the earth building designing are not available in the Czech Republic. The quality research about the unburned earth have to be realized for creating of this instructions. It is necessary to analyse unburned earth properties in dependence on its composition. This is the reason why we investigate

\begin{tabular}{ll}
\hline Mark of clay & Kind of clay \\
\hline GEM & montmorillonite \\
\hline AGL & illite \\
\hline KR & illite-kaolinite \\
\hline
\end{tabular}

TABLE 1. Three basic kinds of clay.

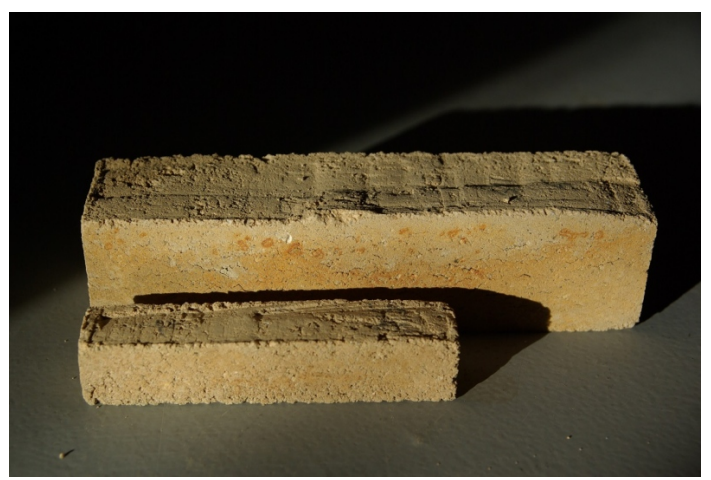

Figure 4. The test bodies shape of block.

the behaviour and properties of the rammed earth from earth mixtures of different composition.

The test earth mixtures are produced in our laboratory from the three elementary components (clay, sand, water). Clay fulfils a function of a binder, sand fulfils a function of a filling agent and water serves for an activation of clay bonding properties and for good earth mixture processing. The composition of the earth mixtures differ in kind of clay, amount of clay or amount of mix water. The amount of water is defined by the water coefficient (see Equation 1). Three elemental kinds of clay were used (see Table 1 ). The summary of the earth mixture which have been made can be seen in Table 2

$$
W=m_{w} / m_{c}
$$

$$
\begin{aligned}
& W \text { - Water coefficient [-] } \\
& m_{w}-\text { Weight of water [g] } \\
& m_{c}-\text { Weight of clay }[\mathrm{g}]
\end{aligned}
$$

Determination of dependence between the rammed earth properties and the rammed earth composition is our goal. Up to now, we have produced 19 types of the earth mixtures and analysed their properties. We focused particularly on the tensile bending strength, the compressive strength, Young's modulus, moisture's properties, methylene blue test, shrinkage, creeping and drying rate.

We used the test bodies of block shape of size $2 / 2 / 10 \mathrm{~cm}$ and $4 / 4 / 16 \mathrm{~cm}$ for majority experiments (see Fig. 4). We used the test bodies of prism shape with octahedron base and height of $7 \mathrm{~cm}$ for measurement of creeping and shrinkage (see Fig. 5). We used the test bodies of block shape of different heights with 


\begin{tabular}{llcc}
\hline Set & clay & Sand/clay weight ratio & Water coefficient \\
\hline GEMI & montmorillonite & $80 / 20$ & 0.370 \\
\hline GEMII & montmorillonite & $75 / 25$ & 0.370 \\
\hline GEMIII & montmorillonite & $75 / 25$ & 0.295 \\
\hline AGLI & illite & $80 / 20$ & 0.370 \\
\hline AGLI & illite & $75 / 25$ & 0.370 \\
\hline KRI & illite-kaolinite & $80 / 20$ & 0.370 \\
\hline KRII & illite-kaolinite & $75 / 25$ & 0.370 \\
\hline KRIII & illite-kaolinite & $80 / 20$ & 0.400 \\
\hline KRIV & illite-kaolinite & $85 / 15$ & 0.295 \\
\hline KRV & illite-kaolinite & $85 / 15$ & 0.370 \\
\hline KRVI & illite-kaolinite & $85 / 15$ & 0.400 \\
\hline KRVII & illite-kaolinite & $80 / 20$ & 0.250 \\
\hline KRVIII & illite-kaolinite & $80 / 20$ & 0.290 \\
\hline KRIX & illite-kaolinite & $80 / 20$ & 0.450 \\
\hline KRX & illite-kaolinite & $75 / 25$ & 0.295 \\
\hline KRXI & illite-kaolinite & $75 / 25$ & 0.400 \\
\hline KRXII & illite-kaolinite & $70 / 30$ & 0.295 \\
\hline KRXIII & illite-kaolinite & $70 / 30$ & 0.370 \\
\hline KRXIV & illite-kaolinite & $70 / 30$ & 0.400 \\
\hline & & &
\end{tabular}

TABLE 2. Summary of the earth mixtures.

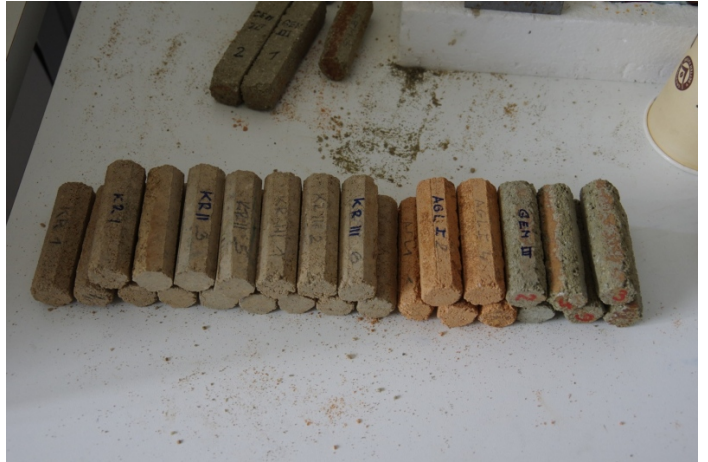

Figure 5. The test bodies shape of prism with octahedron base.

aluminium moulds for measurement of drying rate (see Fig 6).

\subsection{The Production of the Test Bodies}

The earth mixture is produced from three elemental components (clay, sand, water). The clay is fine powder form (see Fig. 7). Size of sand grain is to $4 \mathrm{~mm}$. The grain curve of the sand can be seen in the Figure 8. The water was used from a water supply line.

The three components were mixed and processed into the earth mixture. The earth mixture was pressed

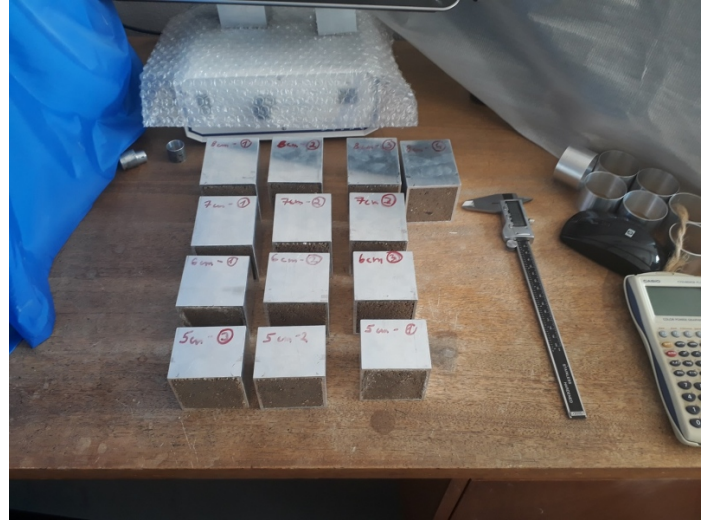

Figure 6 . The test bodies for drying rate experiment.

down to the moulds (see Fig. 9). The test bodies for mechanical properties experiments and moisture's properties experiments were demoulded a few minutes after production and inserted to an air-conditioning chamber. The test bodies for drying rate experiments were left in the moulds and inserted to the air-conditioning chamber. The test bodies were left in the air-conditioning chamber until equilibrium moisture content was reached. Relative atmospheric humidity in the air-conditioning chamber was $50 \%$ and temperature was $20^{\circ} \mathrm{C}$. 


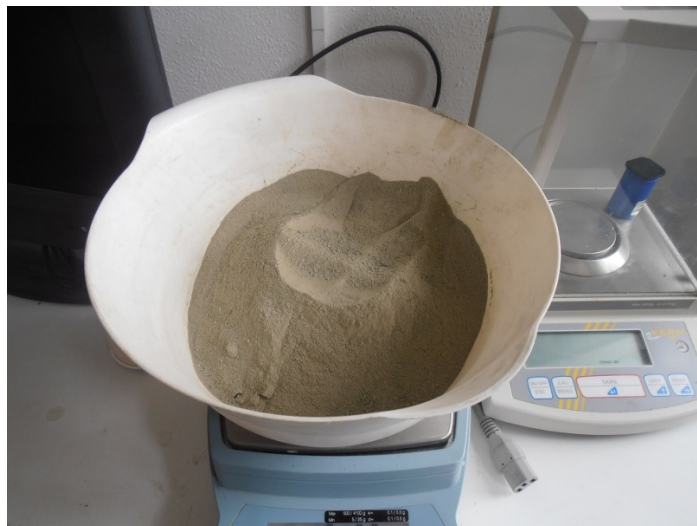

Figure 7. Montmorillonite clay.

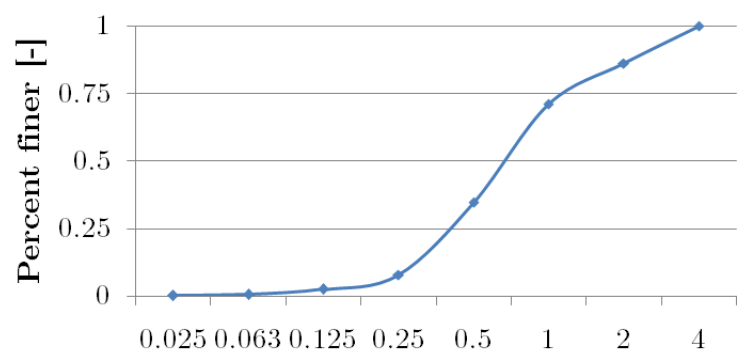

Size of grain $[\mathrm{mm}]$

FIGURE 8. The grain curve of the sand.

\section{The Measure of The Drying RATE}

The test bodies in the Figure 6 were used for the measurement of the drying rate. The earth mixture was pressed down to to the moulds of four sizes. Unidirectional moisture flow of moisture was provided in the test bodies because the test bodies could dry out only by two opposite surfaces. The size of surface for dry out of the test bodies was square shaped of $53 \mathrm{~mm}$ long side. The height of the test bodies (moulds) were $5 \mathrm{~cm}, 6 \mathrm{~cm}, 7 \mathrm{~cm}$ and $8 \mathrm{~cm}$ (see Fig. 10).

The test bodies in the moulds were inserted to the air-conditioning chamber and regularly weighed. Weight decrease of the test bodies was monitored. The moisture content was calculated from the weight of the test bodies by the Equation 2 .

$$
w=\left(m_{w s}-m_{d s}\right) / m_{d s}
$$

$w$ - Moisture content [-]

$m_{w s}$ - Weight of a wet sample [g]

$m_{d s}$ - Weight of a dry sample [g]

Research was focused on the dependence of the drying rate on the thickness of the drying rammed earth (see Fig. 10).

Drying rate was determined for the test bodies. The points of interest in this paper are amount of moisture $50 \%$ and $15 \%$ from original value. From the values

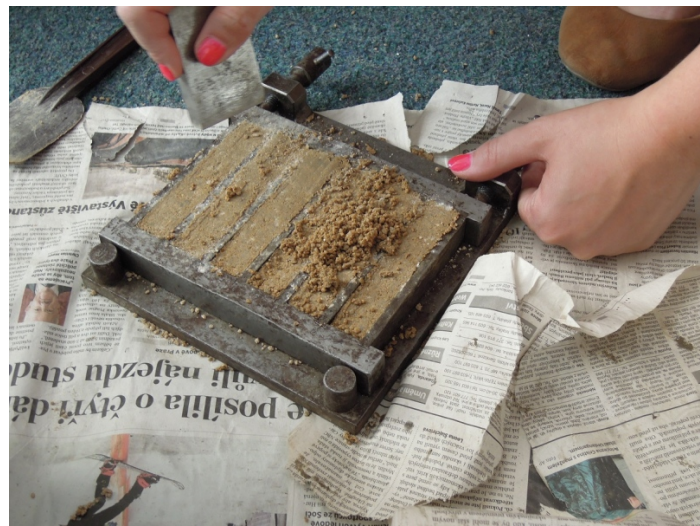

FiguRE 9. The pressing down to the mould.

obtained the drying time from experiment start we tried to determine the drying time of a universal wall.

\subsection{The Measured Data}

The set KRIII is the set of the earth mixture for this drying rate experiment (see Table 2). Number of the test bodies of every height were 3 . Total of 12 test bodies were used for the experiment.

The weighing interval was 15 to 60 minutes in the first 12 hours after production of the test bodies. After first 24 hours the weighing interval was extended.

The moisture content was calculated by Equation 2 The shape of the moisture content curve in time is shown in Fig. 11. A total time for this experiment was approximately 7 day (exactly 167.25 hours). The moisture content after 7 days were $0.6 \%$ to $0.9 \%$ (approximate decrease by $85 \%$ from original value of the moisture content). The main decrease of the moisture content was in the first 24 hours. The moisture content after first 24 hours were $2 \%$ to $2.9 \%$ (approximate decrease by $65 \%$ from original value of the moisture content).

The moisture content $50 \%$ from original value was reached after 8 to 16 hours depending on the height of the test bodies (see Fig. 12. Dependence between the drying rate and the thickness of the rammed earth appears to be linear (see Fig. 13). Time to reach $50 \%$ from original value of the moisture content of different thickness rammed earth is possible determine by drying coefficient $f_{d r y}$. The drying coefficient is defined by Equation 3 .

$$
f_{d r y}=\frac{\sum_{i=1}^{n}\left(t_{i} / h_{i}\right)}{n}
$$

$f_{d r y}$ - Drying coefficient [hour $/ \mathrm{cm}$ ]

$t_{i}$ - Time for drying out of the test bodies of a particular size [hour]

$h_{i}$ - Hight of the test bodies of a particular size $[\mathrm{cm}]$ $n$ - Number of the test bodies heights [-]

The drying coefficient was calculated 1.8 hour $/ \mathrm{cm}$ from the moisture content values obtained. Base on 


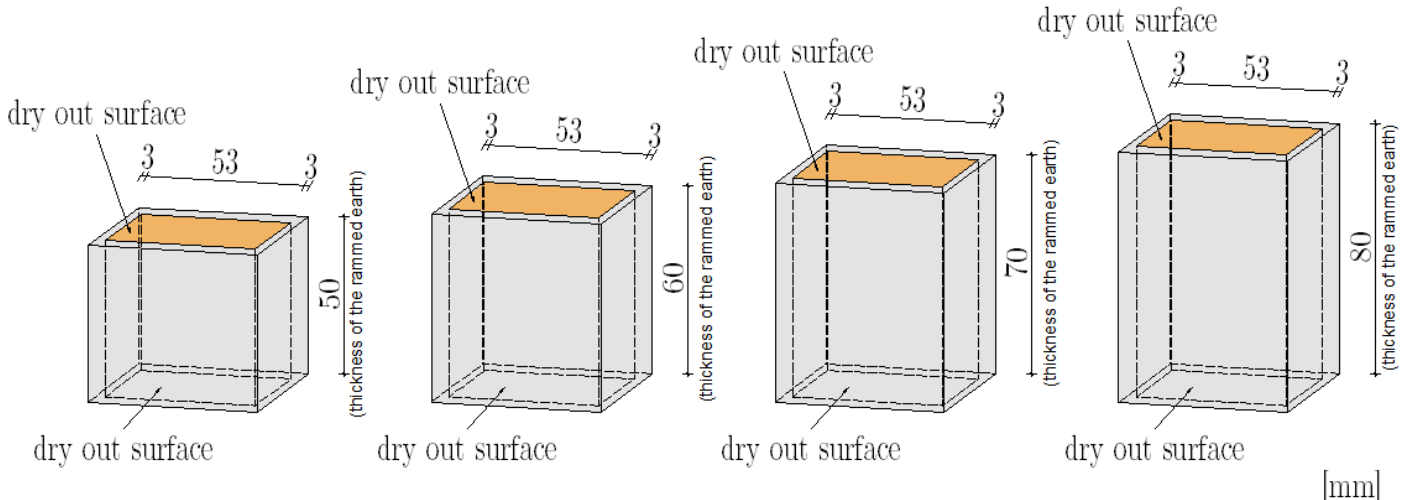

Figure 10. The diagram of the test bodies in the moulds for drying rate experiments.

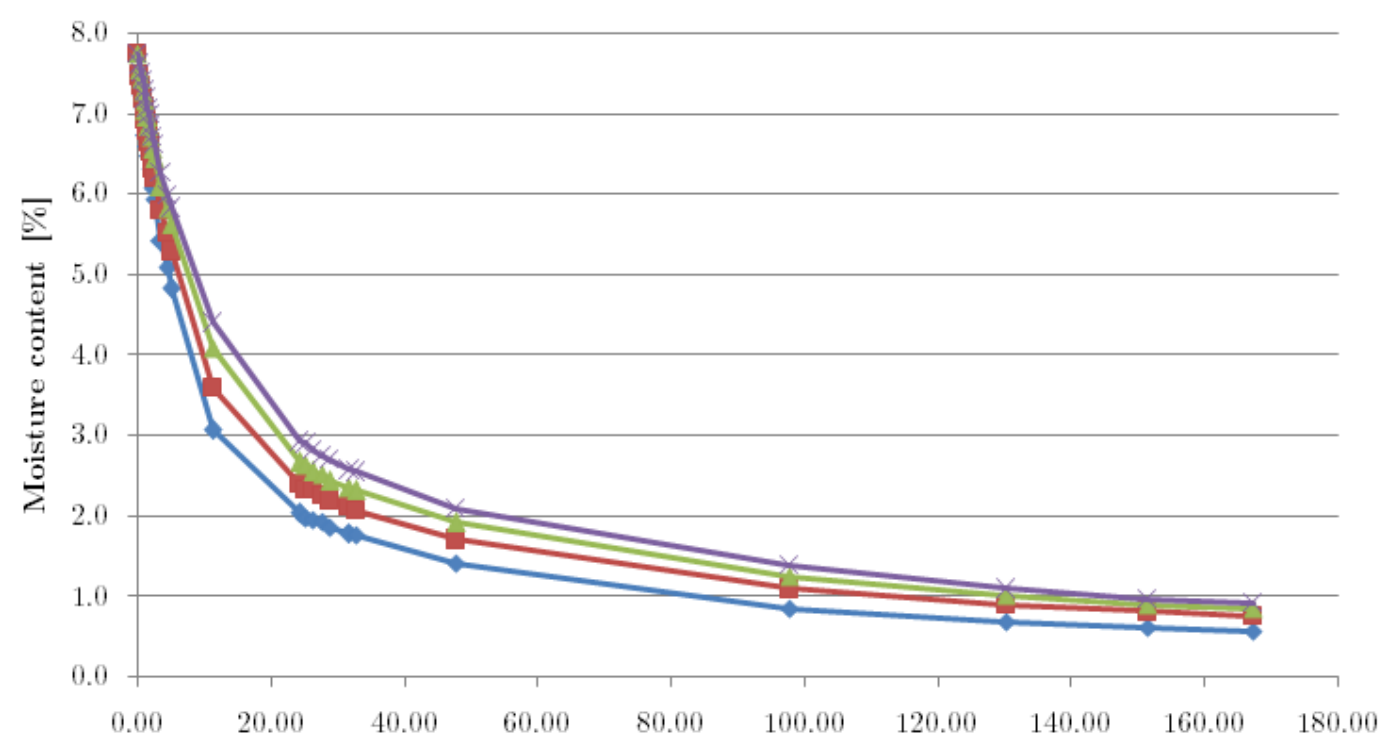

Time [hour]

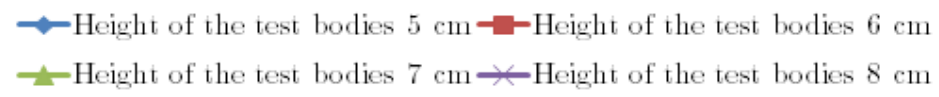

Figure 11. The time course of the moisture content.

the values obtained is possible to predict that, for example, a $30 \mathrm{~cm}$ thick rammed earth wall will dry out from $50 \%$ in approximately 2.25 days. This prediction was done using Equation 4

$$
t_{50}=W_{w} \cdot f_{d r y}
$$

$t_{50}$ - Time for drying out of a rammed earth wall [hour]

$W_{w}$ - Thickness of a rammed earth wall $[\mathrm{cm}]$

$f_{d r y}$ - Drying coefficient [hour/cm]

The decrease of the moisture content from $85 \%$ from original value was reached after 70 to 123 hours depending on the height of the test bodies (see Fig. 14). Dependence between the drying rate and the thickness of the rammed earth appears to be linear (see Fig. 15).

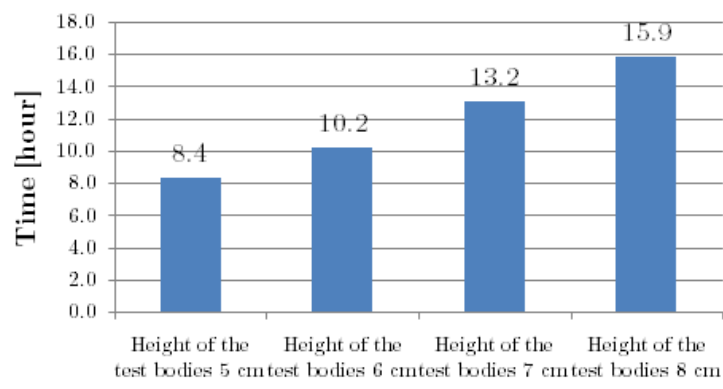

Moisture content $50 \%$ from original value

Figure 12 . The decrease by $50 \%$ from original value of the moisture content.

From the time to reach $85 \%$ of the original value of the moisture content of different thickness rammed 


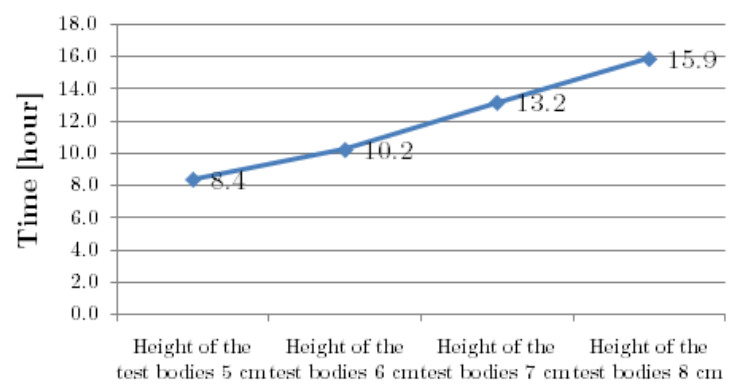

Moisture content $50 \%$ from original value

Figure 13. The decrease by $50 \%$ from original value of the moisture content - linear dependence.

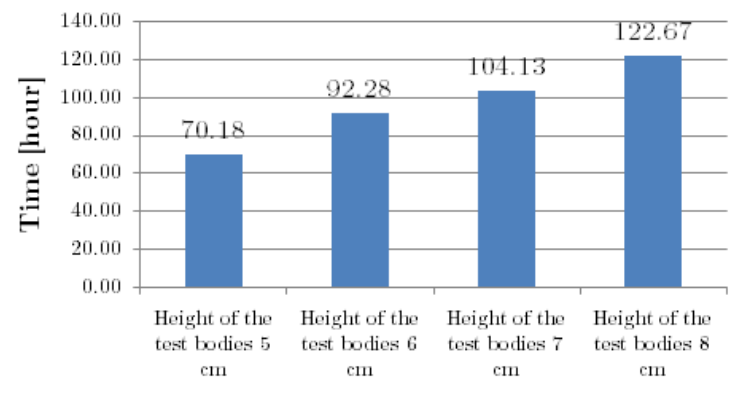

Figure 14 . The decrease by $85 \%$ from original value of the moisture content.

earth is possible to determine the drying coefficient.

The drying coefficient for $85 \%$ decrease of the moisture content was calculated 14.9 hour $/ \mathrm{cm}$ from the moisture content values obtained (see Equation 3). Base on the values obtained it is possible to predict that, for example, a $30 \mathrm{~cm}$ thick rammed earth wall will dry out from $85 \%$ approximately 18.6 days. This prediction was done using Equation 3 .

\section{Conclusions}

The rammed earth structures are usually load-bearing types and that is the reason why it is necessary to know how long after their production the rammed earth has its final properties (in particular mechanical properties). Determination of drying time of the rammed earth of the known composition (set KRIII, see Table 2 was the goal of the drying rate experiment described in this paper.

The decrease of the moisture content was calculated from the measured values of weights of the test bodies. The drying coefficient was determined for the calculation of the drying time of the different thickness rammed earth walls.

The points of interest were $50 \%$ decrease of moisture content from original value and $85 \%$ decrease of moisture content from original value. The prediction of drying time is determined by using the drying coefficient.

From the obtained values was predicted that $30 \mathrm{~cm}$

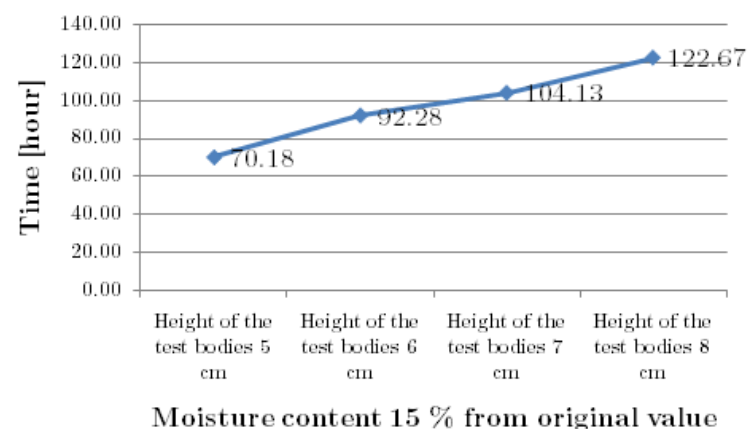

Figure 15 . The decrease by $85 \%$ from original value of the moisture content - linear dependence.

thick walls will dry out from $50 \%$ of the original moisture content approximately in 2.25 days. The drying coefficient for this value is $1.8 \mathrm{hour} / \mathrm{cm}$.

The same walls will dry out from $85 \%$ of original moisture content approximately 18.6 days. The drying coefficient for this value is 14.9 hour $/ \mathrm{cm}$.

\section{LIST OF SYMBOLS}

$W$ Water coefficient [-]

$m_{w}$ Weight of water $[\mathrm{g}]$

$m_{c}$ Weight of clay $[\mathrm{g}]$

$w$ Moisture content [-]

$m_{w s}$ Weight of a wet sample [g]

$m_{d s}$ Weight of a dry sample [g]

$f_{d r y}$ Drying coefficient [hour $/ \mathrm{cm}$ ]

$t_{i} \quad$ Time for drying out of the test bodies of a particular size [hour]

$h_{i} \quad$ Hight of the test bodies of a particular size [cm]

$n \quad$ Number of the test bodies heights [-]

$t_{50}$ Time for drying out of a rammed earth wall [hour]

$W_{w}$ Thickness of a rammed earth wall $[\mathrm{cm}]$

\section{ACKNOWLEDGEMENTS}

The financial support of this experiment by the Czech Science Foundation (GAČR project NO. 18-10884S) and Faculty of Civil Engineering, Czech Technical University in Prague (SGS project No. SGS16/201/OHK1/3T/11) is gratefully acknowledged.

We would like to express our thanks to LB MINERALS, s.r.o. company for free supply of material necessary for experimental measurement and we would also like to express thanks to HELUZ cihlářský průmysl v.o.s. for giving statistical data and informations.

\section{REFERENCES}

[1] Scopus - Analyze search results. https://www.scopus.com/term/analyzer.uri?sid= 8EE866586B66D91CE67A3F34F5AF5EFE. wsnAw8kcdt7IPYL00V48gA\%3a70\&origin=resultslist\& src $=$ s\&s $=$ TITLE - ABS-KEY $\% 28$ rammed+clay $\% 29+A N D+$ PUBYEAR $+\% 3 e+1999 \&$ sort $=p l f-f \& s d t=b \& s o t=b \& s l=26 \&$ count=70\&analyzeResult $\mathrm{s}=$ Analyze+results\&txGid= 8EE866586B66D91CE67A3F34F5AF5EFE. wsnAw8kcdt7IPYLO0V48gA\%3a49

[2] P. Stejskal. E-mail consultation, 2017. 
[3] G. Minke. Building With Earth. Ökobuch Verlag, Staufen, 2006.

[4] A. Jing. A History of the Great Wall of China. World Scientific Publishing Company, 2015.

[5] V. Kovářů. Hliněný dům, problematika jeho památkové obnovy a využití. In Zděná Architektura $v$ Čechách, Na Moravě a ve Slezsku, pp. 31 - 33. 2004.

[6] V. Hájek. Lidová Staveni: Opravy a Úpravy. Stavitel. Grada, Praha, 1st edn., 2001.

[7] P. Jaquin, C. Augarde. Earth building : History, science and conservation. Report, Bracknell : IHS BRE Press, 2012.

[8] C. Sjostorm. Agenda 21 pro Udržitelnou Výstavbu. CIB Report Publication 237. CIB, Rotterdam, 2001.

[9] Institute for Environment and Sustainability (2010) International Reference Life Cycle Data System (ILCD) Handbook. Publications Office of the European Union, Luxembourg, 2012.

[10] H. Schroeder. La transferencia de humedad y el cambio en la resistencia durante la construcción de edificios de tierra. Informes de la Construcción 63(523):107-116, 2011.
[11] J. Hodková. Life Cycle Assessment of Building Products and Buildings, 2012.

[12] ČSN 1168-1939 - PODMÍNKY PRO ZEDNICKÉ A PŘIDRUŽENÉ PRÁCE POZEMNÍCH STAVEB, 1951.

[13] I. Žabičková. Hliněné stavby, vol. 2002. Era 21, Brno, 2002.

[14] Q. B. Bui, J. C. Morel, B. V. Venkatarama Reddy, W. Ghayad. Durability of rammed earth walls exposed for 20 years to natural weathering. Building and Environment 44(5):912-919, 2009. DOI:10.1016/j.buildenv.2008.07.001.

[15] V. B. Reddy, P. P. Kumar. Structural Behavior of Story-High Cement-Stabilized Rammed-Earth Walls under Compression. Journal of Materials in Civil Engineering 23(3):240-247, 2011.

[16] S. Mindess. Concrete. Prentice-Hall,, 1st edn., 1981.

[17] P. Walker. Rammed Earth: Design and Construction Guidelines, vol. 2010. IHS BRE Press, Watford, 2010. 